\title{
Social Media and On-Line Political Campaigning in Malaysia
}

\author{
Sara Chinnasamy, Izyan Roslan \\ University Technology Mara, Selangor, Malaysia \\ Email: sarachinnasamy@outlook.com
}

Received 27 October 2015; accepted 25 December 2015; published 30 December 2015

Copyright (C) 2015 by authors and Scientific Research Publishing Inc.

This work is licensed under the Creative Commons Attribution International License (CC BY). http://creativecommons.org/licenses/by/4.0/

(c) (i) Open Access

\section{Abstract}

Since the controversies surrounding the 2008 and 2013 Malaysian general elections due to the rising popularity of Opposition, social media networks have played a vital role in conveying political messages and debates. The social media continues to report significantly in the 2014's state by-elections on the political unrest issues especially an allegation on the Malaysian famous Opposition leader, Anwar Ibrahim. The Kuala Lumpur Court of Appeal found him guilty of sodomy and sentenced him to five years jail, which disqualified him from contesting the Selangor State Assembly seat of Kajang on 23 March 2014. He was expected to win this election and further had opportunity to be elected as the chief minister of Selangor state, the country's main economic hub surrounding Kuala Lumpur. In another tragic event, which was spotted on the social media coverage was the death of another well known Opposition politician, Karpal Singh, "the Tiger of Jelutong", following a motor vehicle accident. This has caused another by-election taken placed at the Bukit Gelugor, Penang. Yet, this paper takes a closer lens, on Kajang by-election and analyzes how the Facebook had been utilized for the Opposition leader, Dr. Wan Azizah Wan Ismail's (Anwar Ibrahim's wife) victory in the election. Using compliance gaining theory, this paper presents strategies used by the two major political parties, Barisan Nasional (BN) and Pakatan Rakyat (PR) to achieve their electoral goals. Though online political campaigning is not new from a Western perspective, it is for a semi-democracy country like Malaysia. To understand how the compliance gaining approach works in practice, selected political parties' Facebook advertisements are examined within two weeks after nomination day and election observers from diverse backgrounds are interviewed. It can be concluded that since 2008 political messages have been heavily debated through blogs. Independent Internet Media, Facebook and Twitter are very popular among Malaysian political candidates and voters.

\section{Keywords}

Social Media, Facebook, General Elections, By-Elections, Kajang 


\section{Introduction}

An election can be defined as the contest for the highest stakes in national politics. The electoral system is a set of predetermined rules for conducting elections and determining their outcome. In Malaysia, elections were held before it achieved its independence in 1957. Malaysia conducts general elections every five years, and its democracy has been described by scholars in terms such as "quasi democracy" (Zakaria, 1989), "semi-democracy" (Case, 1993), "modified democracy” (Crouch, 1993), "Democracy a la Malaysia” (Muzaffar, 1989), “democracy according to our own mould" (Hassan, 1997) and "pseudo-democracy" or as "flawed democracy" (Tan \& Ibrahim, 2008). Chinnasamy (2013) argues these terms, denoting gaps or flaws, in themselves, and demonstrates that democracy in Malaysia strains the usual categorisation procedures. Intelligence Unit's Democracy Index (2011) indicates that Malaysia is in the 71st place among "flawed democracies".

The conduct of elections in Malaysia continues to attract global and local attention. At present, Malaysia has two types of elections. Firstly, general elections are held once every five years, and secondly, by-elections are held locally. The latter do not involve the dissolution of any assembly, and do not follow a fixed schedule, because they occur on the sudden death of a Member of Parliament or a particular political candidate changing from one political party to another. Thus, elections are considered democratic practices that forge the link between the people and political candidates or party to form a government.

The BN is a government party, a coalition of fourteen primarily ethnically-based political parties that have ruled the country since independence in 1957. The 2008 general elections result portrayed the public's partial rejection to the BN government. It was perceived as forceful and unexpected, and described as a "political tsunami” (Asli, 2008; The Star, 9 March 2008a). It was the BN's worst performance in Malaysia's electoral history (Oorjitham, 2008; Sani, 2005; Welsh, 2004). The rising popularity of the Opposition, namely Pakatan Rakyat/People's Alliance (PR) in the 2008 and 2013 elections had much to do with the success of former Deputy Prime Minister (DPM) Anwar Ibrahim, who unified the three Opposition parties (the People's Justice Party (PKR), the Democratic Action Party (DAP) and the Pan-Malaysian Islamic Party (PAS)) under one umbrella. This was known as PR after GE2008. In the GE2013 the BN won a bitter election, taking 133 out of 222 parliamentary seats. In contrast, in the GE2008 the BN had 140 seats (Chinnasamy, 2013).

In Malaysia's election whether it is general elections or by-elections, political advertisements have played a vital role even though advertisements remained traditional tools in the GE2008. Networking sites and political advertisements were not so developed during this time. The BN and its candidates employed traditional methods such as posters, political rallies, small group discussions (ceramah) and door-to-door efforts; a "sledgehammer" approach focused on the BN's achievements with the slogan "Security, Peace and Prosperity" (Moten, 2009). Moten stated that in the GE2008, the BN had bought 1100 pages of full colour advertisements in the print mainstream media to attract voters. Yet, the Opposition parties used the Internet skillfully to highlight BN government's poor performance and weakness. Before the election, most of the Opposition parties' leaders had their own social networks such as Lim Kit Siang (www.limkitsiang.com) and Anwar Ibrahim

(www.anwaribrahim.com), which discussed their political activities, the government's malpractices and its failure to develop certain projects.

Political advertising consists of political campaigns putting out political messages to the public. Any communication process has involved communication channels and the media (Shireen, 2008). Political messages that have to be conveyed using advertisements or campaigns must be appropriate to make voters get the information and then trust whoever provides it. Campaign advertisements strong in sophisticated content and advertising bring information in a systematic way. Like product advertising, political advertisements are methodically tested and professionally produced. Freedman et al. (2004) argue that text, image and music work to strengthen each other. An advertisement's primary message is to recognize easily. By using advertising as a medium of political campaign will make voters influence to vote for their choices. Using text or images helps them to vote for a certain politician. Nevertheless, political advertisements work differently at various campaign moments. Because they are different and complicated in their structure, it is difficult to classify them into groups either by class of text such as announcements, declarations, exhortations or information (Guy, 2001). Political advertisements wield much influence and they are the only way to show abilities of candidates as leaders who communicate with the voters.

Advertising now leads campaigns and new media technologies have provided them with new ways to influence media messages. Journalists recognized the importance of voters needing to be supplied with independent information such as advertising messages (Kaid, 2009). Parliamentary activities generally change all the time 
(Andrew, 1992). In order to comprehend how democratic politics supply this social end, we must understand that the social role is achieved, as it were, incidentally; in the same sense as production is incidental to the creation of profit. This influences political candidates to start their political campaigns and change voters' perceptions. Contemporary voters use the mass media for most of their information about political candidates and issues. Sometimes, the political candidates provide information that can be controlled openly and usually it is in the form of televised political advertising.

This paper focuses on a by-election held for the Selangor State Assembly seat of Kajang on 23 March 2014, due to the resignation of the incumbent assemblyman, Lee Chin Cheh on 27 January 2014

(Themalayianinsider.com, 2014). Cheh was contested under the ticket of PKR, PR coalition. He won by a majority of 6824 votes against 5 other candidates in the GE2013 (Channel News Asia, 2014).

From the nomination day, 11 March 2014 until the polling day, both BN and PR candidates (mainly Dr. Wan Azizah-PKR and Chew Mei Fun-BN) were actively engaged on social media networks and especially Facebook. Facebook has become the most used social media website globally and replaced printed media or broadcast media. This was proved after Dr. Wan Azizah won the election. The Internet changed communication patterns and increased communication channels for people. In the election campaign Facebook provide awareness to people, helping promote candidates and display election results.

Social networking sites have proved successful in gaining voters' trust and at the same time spread the political beliefs and policies of candidates better than the broadcast media or print media. In the US, the Internet was used to raise huge amounts of money through personal websites, such as my.BarackObama.com, and Facebook and Twitter (Chinnasamy, 2013). Pew (2008) reported that one in ten Internet users donated money to a candidate. Howard Dean, former Vermont Governor, claimed that the Internet was a promoter and reviver of democracy due to his large online fundraising in the 2004 campaign (Williams \& Tedesco, 2006). Although his presidential campaign was unsuccessful, Dean was regarded as a pioneer in raising the profile of Internet-based fundraising and grassroots organising (Center for Public Integrity, 2005). In the US presidential election of 2008, Barack Obama created a record by fundraising $\$ 532,946,511$ in a few months from individual small donors (Hitwise, 2008), while Ron Paul, Representative from the Texas $14^{\text {th }}$ district, raised a record $\$ 6$ million dollars in one day via the Internet (Vogel, 2007). Thus, the Internet proved extremely useful in electoral gains and it became an important tool for political communication.

\section{Research Aims}

This paper aims to investigate the impact of political advertising on the Kajang by-election through Facebook; the extent it influenced the voters in the decision-making process. Furthermore, the inclusion and exclusion of Facebook's political advertisements by both political parties (the BN and the PR) and political candidates will be explored. Every political candidate has his or her own strategies in conducting political campaigns. The paper will assess how people were aware of those advertisements and how they impacted on them. Using Kajang's by-election as a case study, this paper also discovers if Facebook was important in political campaigning. The difference between the mainstream media news and social networks news, which been posted by some of the independent news portals (INP) will determine the electoral outcome, and which medium of popular news consumption influenced voters. This argument will be further strengthened with important key informant interviews.

\section{Compliance Gaining Social Media Advertisements}

Scholarly work on compliance research has analyzed how various techniques process information and target or influence people. Most analyses attempt to recreate an accurate construction of the situation and respond accordingly to it. Compliance-gaining theory aims to comprehend the strategies we use when we want to dominate others (Dallinger, 2003). Shelly (2003) suggested compliance is used by people in different ways. The individual will specify which strategies are necessarily and/or ethically adequate. In the social media campaign for elections, political candidates had to work hard to gain people's trust in order to be seen as credible.

Compliance-gaining is made up of "persuasion" which highlights beliefs, attitudes, attention and behaviors while the term "compliance" typically refers to a transformation in a person's overt behavior (Michelle, 2002). Existing research claimed compliance-gaining strategies influence people and get attention from others in discrete ways. The theory was constructed to explain build interpersonal communication (Schmitt, 1967). O’Keefe 
(1988) sees it as aiming to achieve multiple if conflicting goals while to Deborah (2000) it an attempt to change another person's attitudes. In political advertisements the politicians have their own targets to influence and convey messages that articulate specific goals. The compliance-gaining approach can be applied to this study on how political candidates use social media advertisements to get people's votes. Social media is an electoral medium that links political candidates and targeted voters. Campaigning activities will be announced and updated on Facebook that the public can access. Thus, compliance gaining explores how political candidates utilized Facebook to gain people's trust in this particular by-election. These include how the candidates structured their messages and complied with people's wishes for leaders to follow the rules.

\subsection{Political Advertising}

Political advertising is an important element when a political party wants to attract voters during an election. The major function of political advertisements is to convey messages from candidates to their voters. While Christina et al. (2006) agree that political advertising is a medium that candidates use to promote themselves, Kates (1998) claims politicians engage with media in different contexts. They use it to build their images, clarify their platforms and convey messages to the public. Political advertising has to be effective under certain conditions for different types of voters, image development, agenda setting or attacking opponents. Valentino et al. (2004) highlighted that information in political ads may replace other kinds of information. These findings confirm the view that citizens are cognitive misers who retain some general and limited, request for political information.

Furthermore, looking for information requires effort, and even the most aware will not apply that effort unnecessarily according to Vincent (2004), who states that one probably unique benefit of exposure to political advertisements is that benefits citizens who are uninterested or uninformed about politics. Advertising seems to influence the least aware most powerfully, apparently because those citizens are looking for simple decisions upon which to base their electoral choice. The definition of political knowledge according to Charles (2010) is an individual's ability to recall candidates' names, personal characteristics, and qualifications; to recognize election issues and current campaign developments and to recognize connections between candidates and issue positions. Furthermore, the collision of general mass media campaign communications on gains in knowledge has been contingent in numerous voting studies, based on finding in a moderate_association between media exposure and campaign-related knowledge. Recent research evidence indicates that television advertising supplies voters' knowledge levels. McClure and Patterson report that about three-quarters of the voters who recalled seeing a political advertisement in the 1972 presidential campaign could correctly identify the ad's message. The effect of political messages was straightforward like a hypodermic needle (Franz \& Ridou 2007). It can be said that political advertisements impact on voters who will be persuaded by what they see. Ernest et al. (2013) argue such intense uses of political advertisements have many problems in politics.

Moten (2009) stated that the use of political advertisements in Malaysia has widened over the past years particularly as elections beckon and they are the main communication tool for a party. They have been widely used by various political parties and electoral candidates over the past two decades. Studies have found that political campaigns are not only using traditional ways but also using new media. In a developing country like Malaysia, this improvement makes political campaigning an interactive process. Previous research has helped to explore the Kajang by-election in the context of examining how social media networking helps candidates win.

\subsection{Facebook Approach}

Social networking platforms like Facebook and Twitter are a form of two-way communication (Thomas 2012). The study found that some social media platforms, such as websites and the blogosphere, embody two-way communication with asymmetric responses, allowing for site visitors to leave comments, but without removing the host's voice. Social networking provides people with indirect communication experiences. Twitter is a medium of political campaigning, and recent studies by scholars have found that Facebook is now a main medium for political campaigning. Christine and Girish (2008) argue that the arrival of social networks had signified a further major divergence in elections since 2008. Facebook appeals to a youthful demographic that has unexpectedly increased participation levels. Facebook facilitates candidates’ supporters to develop interpersonal links regarding his/her activities. The social media is able to organize members according to where they live, manage their profiles, networks and organize offline meetings. 
Westling (2007) highlights the importance of social media as the only method of campaigning that get an effective response from the public. Since the Howard Dean campaign in 2004, political strategists perceived that the Internet can measure the interest of the public as well as connect community members to the political process. Thus, Facebook is able to arrange and interact with supporters in a very efficient way. At the same time, it provides members of the public with the ability to voice their thoughts and organize autonomously (Westling, 2007). Facebook is also a platform where candidates and voters can communicate and acknowledge the democratic process (Christine \& Girish, 2007, 2012). The social network formed a matching section within a main site called_Election Pulse in the US. This feature provides much information about the candidates and their profiles in states and districts. Scholars recognized Facebook's victory in the 2008 US presidential election. Political candidates were given online pages for profile placement that were parallel with personal profiles. Candidates are able to post online various kinds of campaigning materials, for example campaign activity announcements, links to other pages such as video sharing YouTube, candidate notes, photo albums, and events that allow voters to post their own comments. This was evident in Canada where Tamara (2008) asserted that Facebook was just one part of the complicated on-line strategy of the Canadian political parties. Though several parties had utilized other political websites that had a narrower focus, the impact of Facebook on electoral politics still needs to be assessed. It can be concluded that Facebook does have an impact on political campaigns in and these include events in Malaysia.

\section{Methodology}

The qualitative method is used to measure the effectiveness of Facebook's political campaign in the Kajang by-election. Elizabeth and Kate (2009) explain that qualitative research focuses on the details of social phenomena and help in understanding the real social world. This method is effective and produces good results because it explores the topic and objectives of the research. This argument is also supported by Patton and Cochran (2002) who state that qualitative research generates more and better data than numbers through use of study informants. Such an interpretation can be applied to the case of the Kajang by-election. This study examines how BN and PR (PKR) political candidates promote their abilities and political messages to Kajang people using advertising in social online networking websites. Furthermore, of the variety qualitative research methods, I selected textual analysis, in-depth interviews and an online research strategy, after establishing the political context of the period studied. There is potential for researcher bias, which has been suggested as a limitation of this method (Lester, 1999). Purposive sampling was necessary to establish two categories of research respondents, i.e. media practitioners as one group and journalists and observers constituting the other.

Textual analysis is used to portray and clarify the characteristics of an evidence or visual message that expresses the content, structure and roles of messages contained in media texts (Frey et al., 1999). The main deliberation in textual analysis is to choose the types of texts to be studied, obtaining proper texts, and then analyze them. If versen (2003) argues that this type of analysis is linked to the linguistic form that associates memory with testimony and testimony with writing. Textual analysis is also known as discourse analysis, and it is a significant way in which to observe cultural artifacts or texts to ascertain their meaning (Matthew, 2008). By connecting the circumstances of production to the review of content this will help to see how institutional and professional control of the text is maintained.

Facebook is the unit of analysis. The sample of this study is drawn from Facebook starting from the nomination day on 11 March 2014 until polling day on $23^{\text {rd }}$ March 2014. The focus will be on how political candidates advertised their political campaigns during the Kajang by-election. Facebook's text will be analyzed and findings will be explained. The connection between media text and the social message will be examined in terms of determining the framework that politicians use to attract voters. The findings will be interpreted from textual analysis and in-depth interview. The results will reflect how effective social media advertisements were during the 12-day campaigning period. Below are examples of screen shots from Facebook (Figure 1 and Figure 2). Graphics, text and all information will be analyzed from the collected data to produce explanations on what they mean.

In analyzing the text the emphasis is on the political advertising in terms of news coverage on Facebook. Thus, the focus is only on candidates in the Kajang by-election. This analysis will examine the meaning of the text in advertisements and visuals that persuade voters to make their choice. The graphics that appear in advertisements present an opportunity to study candidates' stands during their political campaigns. 


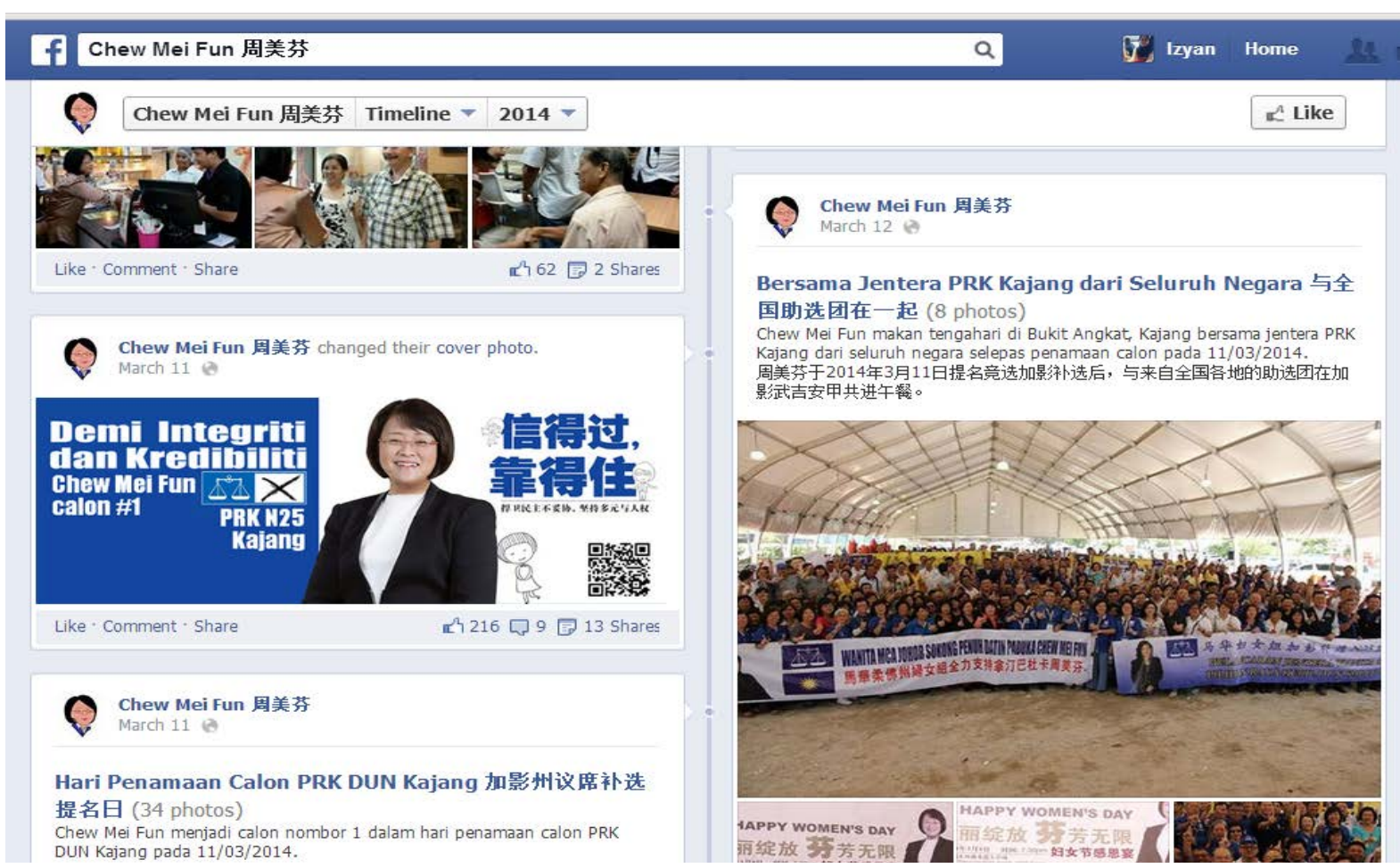

Figure 1. Screenshot of the BN candidate, Chew mei fun facebook (12 March 2014).

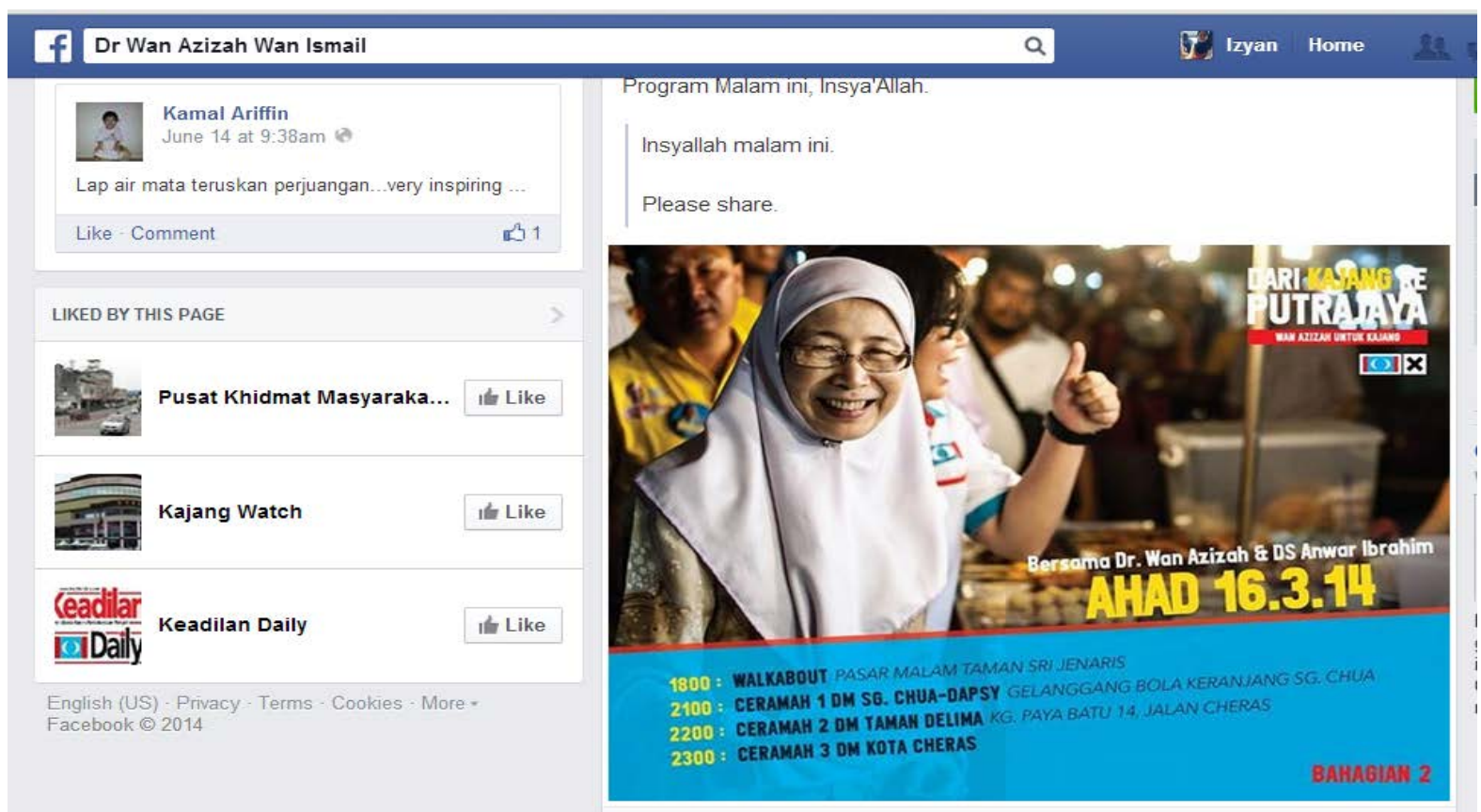

Figure 2. Screenshot of PKR candidate, Dr.wan azizah facebook (16 March 2014).

In-depth interviews constitute another way to collect data by interviewing knowledgeable and experienced people. Informants include nine respondents such as scholars, non-governmental organizations (NGOs), and advertisers who will be referred to as R1 - R9 (i.e. respondent 1 to respondent 9). These respondents were selected based on their experience in political discourses and also their role as political observers. The interviews conducted in Kuala Lumpur to discover their perspectives on a particular idea, program or situation. Informa- 
tion-rich feedback and opinions on the Kajang by-election will be obtained from the in-depth interviews. Known as an unstructured interview, this method helps to acquire information from the interviewee's point of view or situation (Patton 1987). This type of interview involves asking informants open-ended questions to obtain data, specifically relating to the Kajang by-election.

\section{Results}

\subsection{Political Advertising}

Thematic analysis is used to analyse the themes or messages that appear in Facebook political advertisements. The research question focuses on the effect, influence and perceptions of voters regarding political campaigns, and will generate descriptive answers from respondents. Thematic analysis is an expressive way to present qualitative data (Rosemarie, 1997). Braun and Clarke (2006) argue that thematic analysis does not require detailed theoretical and technological knowledge of approaches such as grounded theory. It can offer a more accessible form of analysis. For instance, thematic analysis was used by Sindane (2010) to analyse South African political parties' advertisements on television. The answers from the textual analysis and interviews done will lead to focused and specific conclusions. In the Kajang by-election, BN had two candidates who used social media: Chew Mei Fun and Fauzi Zahari. For the PR, Dr. Wan Azizah and Azmin Ali (PKR) used Facebook (Figure 3).
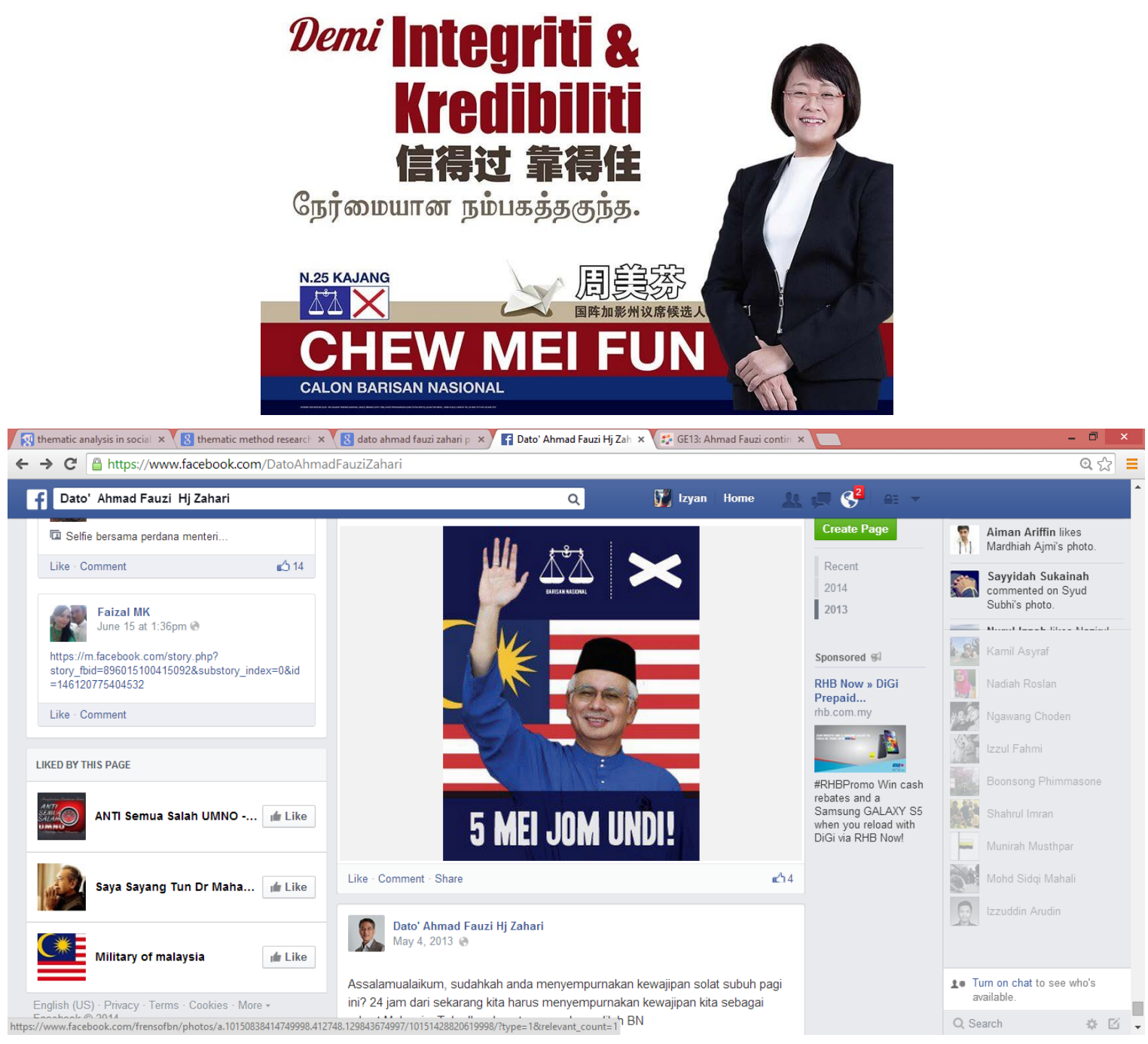

Figure 3. BN candidates. 


\section{1) Promoting Leadership}

The advertisements produced by BN promote the concept of leadership, which emphasizes a candidate's credibility and how they attract voters. Most BN advertisements covered the important themes in one advertisement in order to get the message across simply to voters. Both BN's statements promote BN leadership, but these did not lead to the expected results in the 2008 and 2013 elections. In contrast, the PKR advertisement promoted leadership better than BN and this change people's ideas and their voting decisions. Below are some samples (Figure 4).

In PR candidates' advertisements, certain elements attracted voters to get them to participate. On Azmin Ali news coverage on his Facebook page, he claimed to solve problems in his area by becoming involved with people's activities; this helped to cement his relationship with voters. The activities undertaken by PR will con-

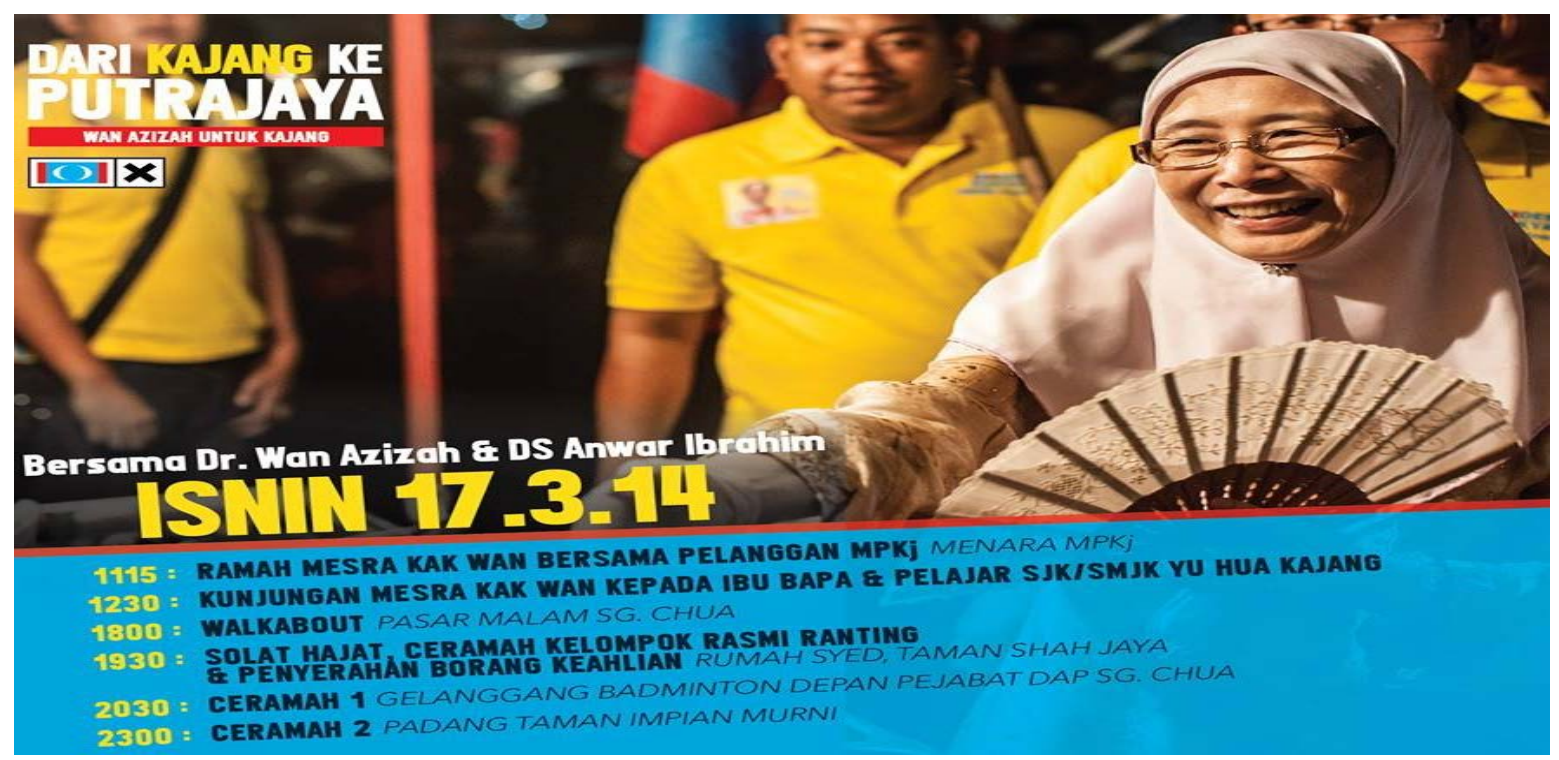

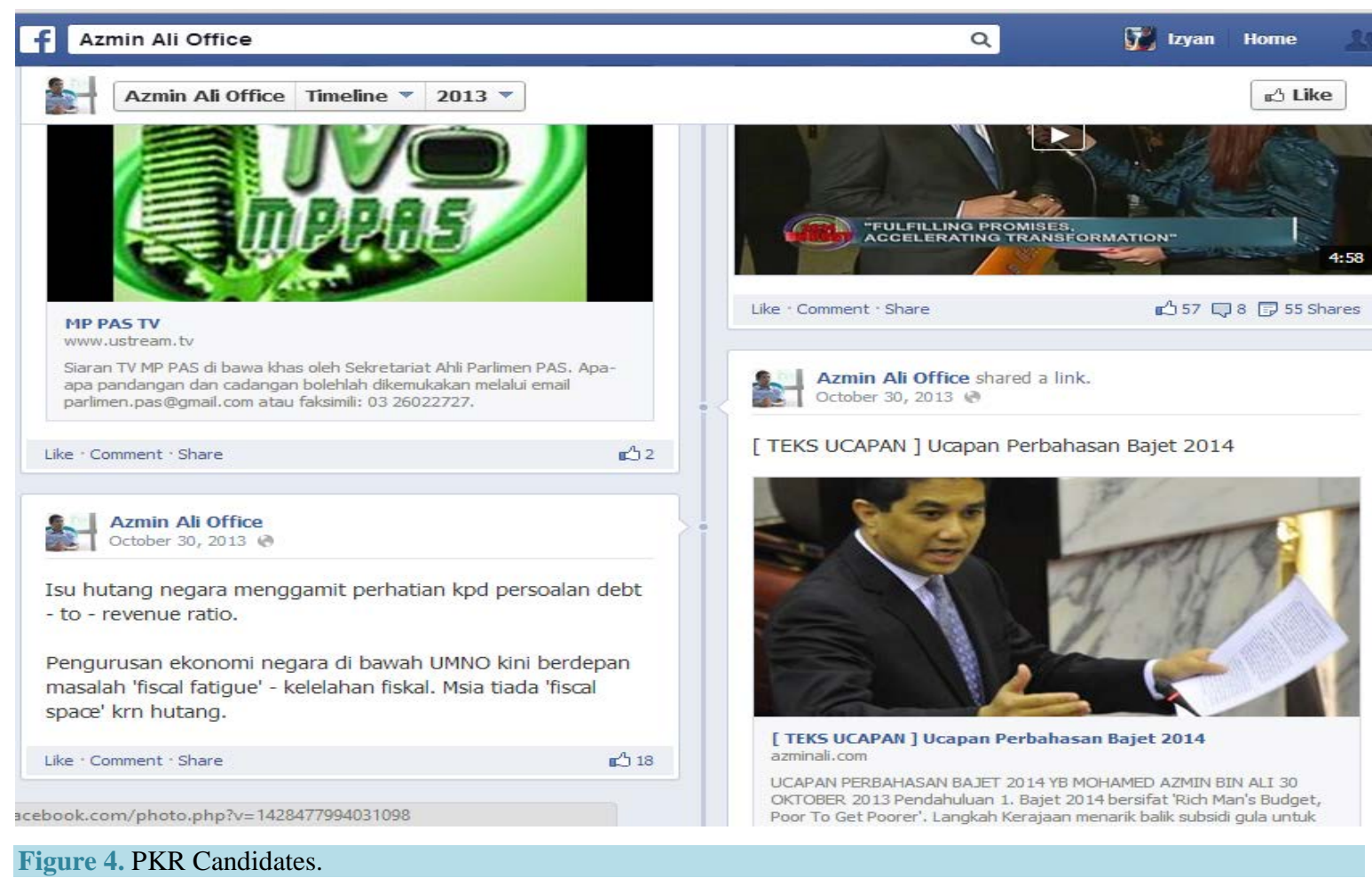


vince voters and at the same time improve their election results, which occurred in 2008 when they won 5 seats unexpectedly. The advertisements reveal that promoting leadership was the priority for the political parties. The main difference between BN and PR were the extent to which they accepted into voters' lives and sense of trust. In every election both parties tried to improve their campaigns through their own social media by promising better leadership and improved lifestyles.

\section{2) Promoting Benefits}

Using the examples below (Figure 5 and Figure 6), it can be seen that both political advertisements focus on the benefits of choosing the candidates of a particular party. BN has used social media more than television or radio for political advertising purposes. This is because it is focusing on promising what it can and will do for people who vote for it. PR did the same thing in its political advertisements but there are some differences their approach to promoting their message.

The sample advertisements above are from the Facebook pages of PR candidates (Figure 7). Their campaigns highlight the benefits of choosing them to govern. As can be seen from the results in the Kajang by-election, PR candidates attracted more voters better than the BN because their method of messaging and the themes they covered were more effective in fulfilling voters' hopes.

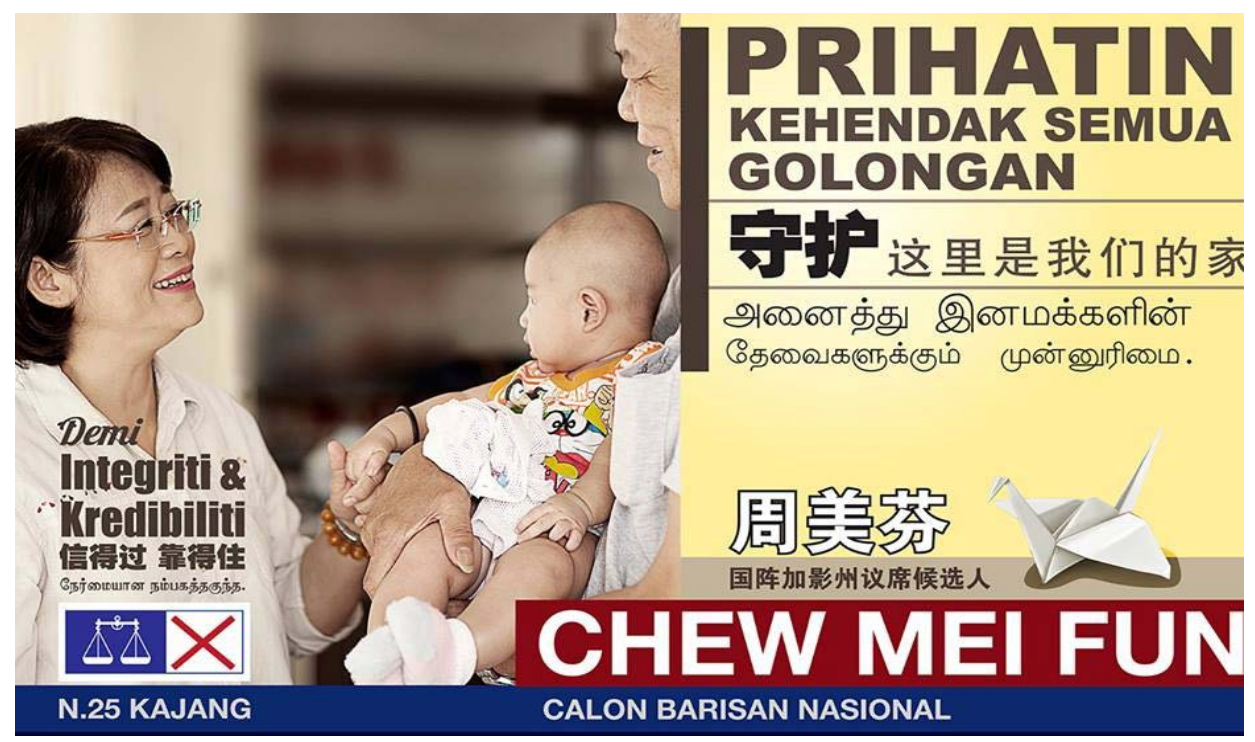

Figure 5. Advertisement on the benefits of voting for the BN.

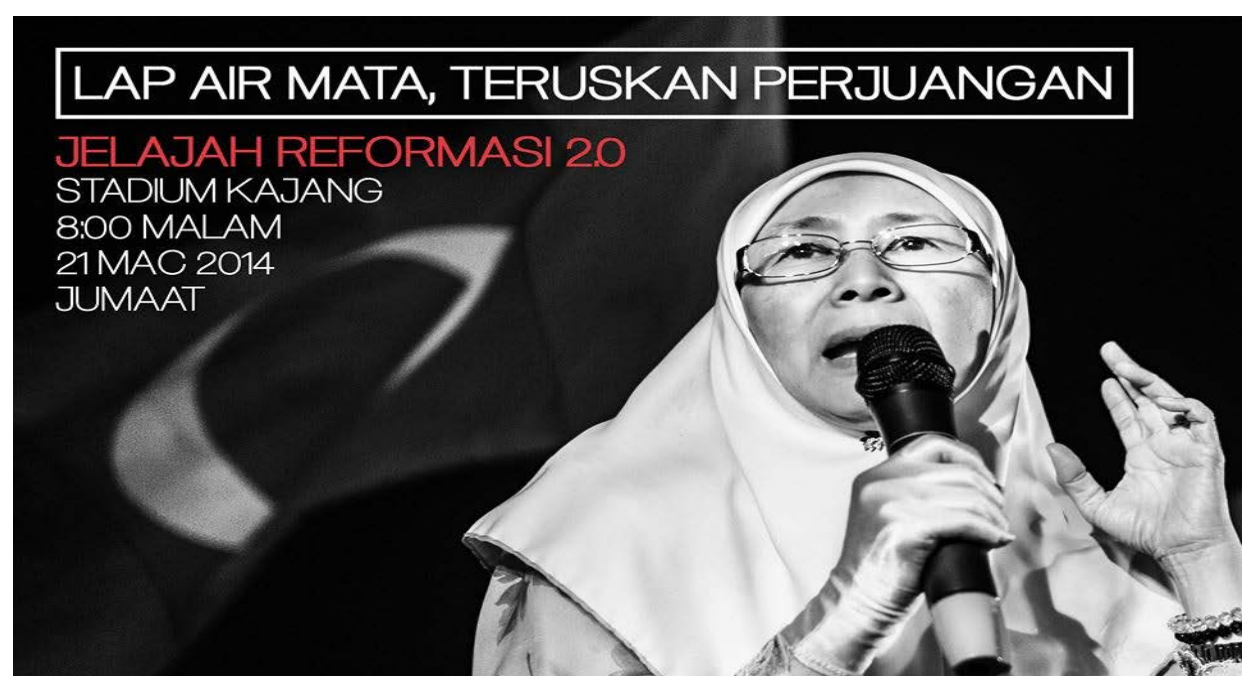

Figure 6. Advertisement of raising sympathy by PR candidate. 


\section{3) Promoting Honesty}

In the Kajang by-election campaign, personality elements were promoted by both parties' candidates. Issues that personally affect a politician will lead to a damaged image or reputation. The BN candidate Chew Mei Fun faced a controversy in that it was rumored she employed and abused a maid, which she denied on her Facebook page (Figure 8). While her reputation was damaged she gained the respect of voters when she finally admitted her fault. In contrast the PKR candidate, Dr. Wan Azizah, is seeking sympathy from voters (Figure 9).

In the advertisement above, the slogan used "Lap Air Mata, Teruskan Perjuangan/Wipe your Tears and continues your struggle" shows is seeking sympathy from Kajang voters. As Malaysians were aware Anwar Ibrahim was replaced by his wife Dr. Wan Azizah who contested the election. The sympathy approach brought her

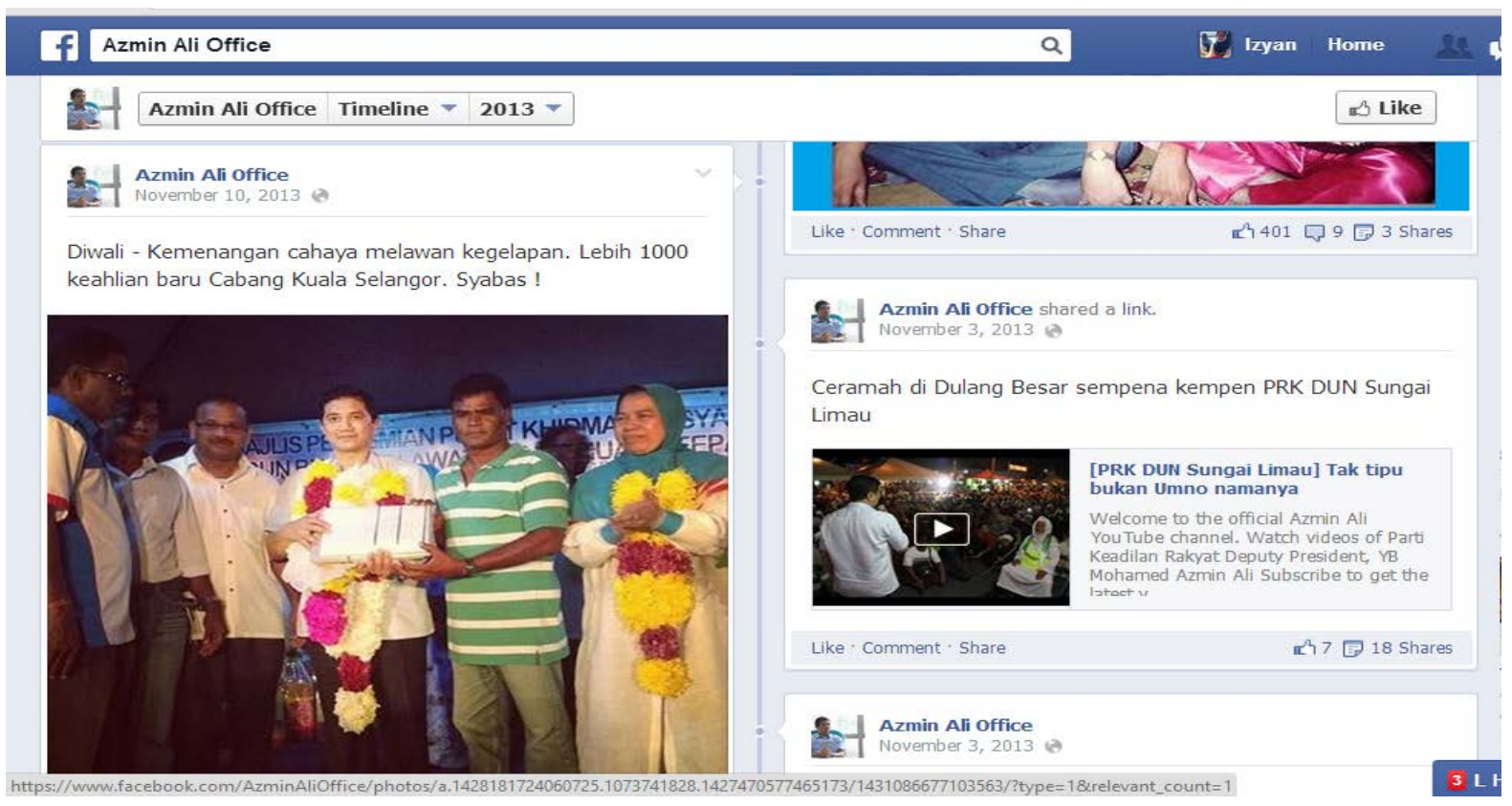

Figure 7. Advertisement of promoting the candidate himself and his activities.

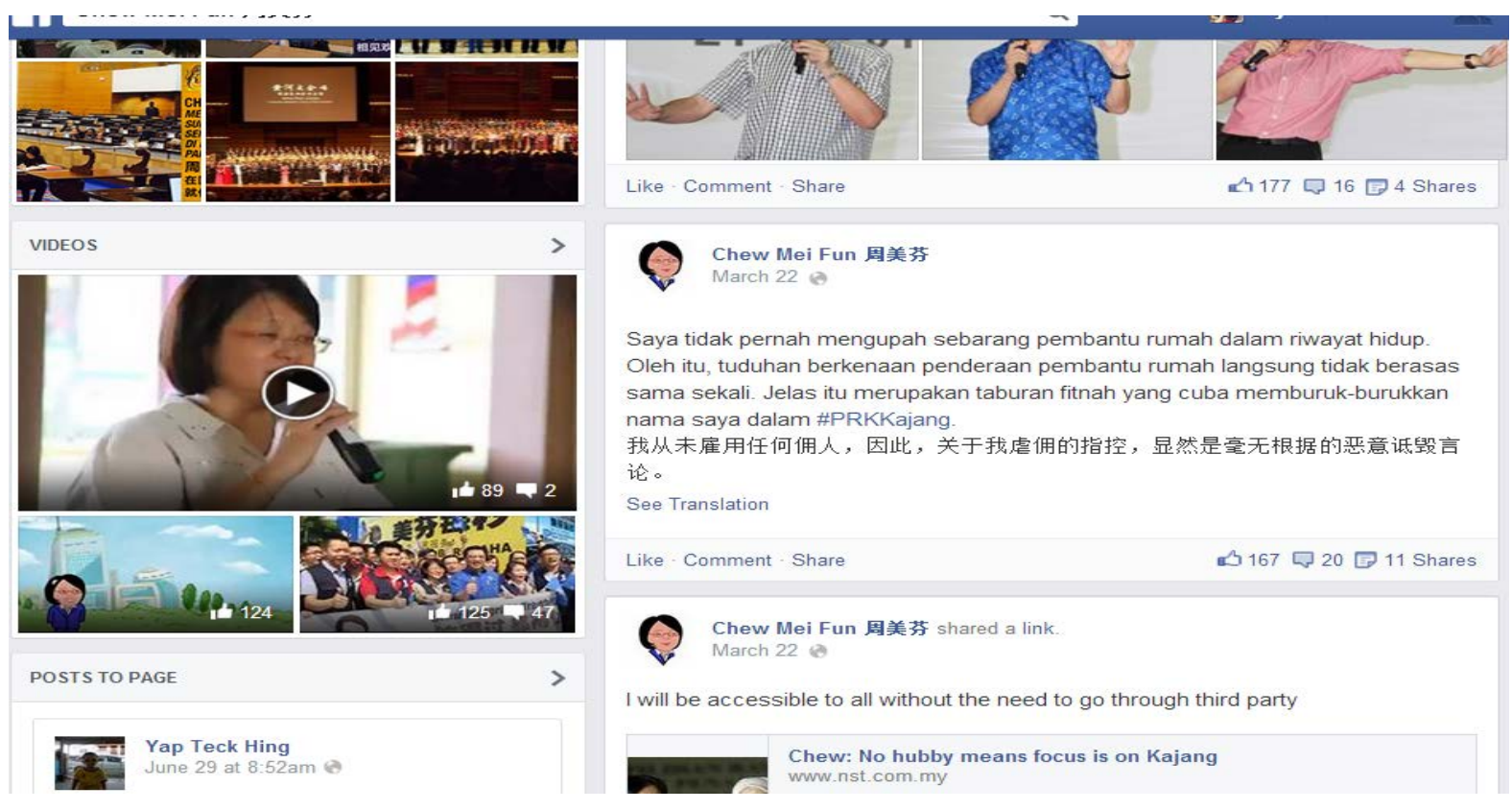

Figure 8. BN's chew mei fun's statement on maid abuse case (2014). 


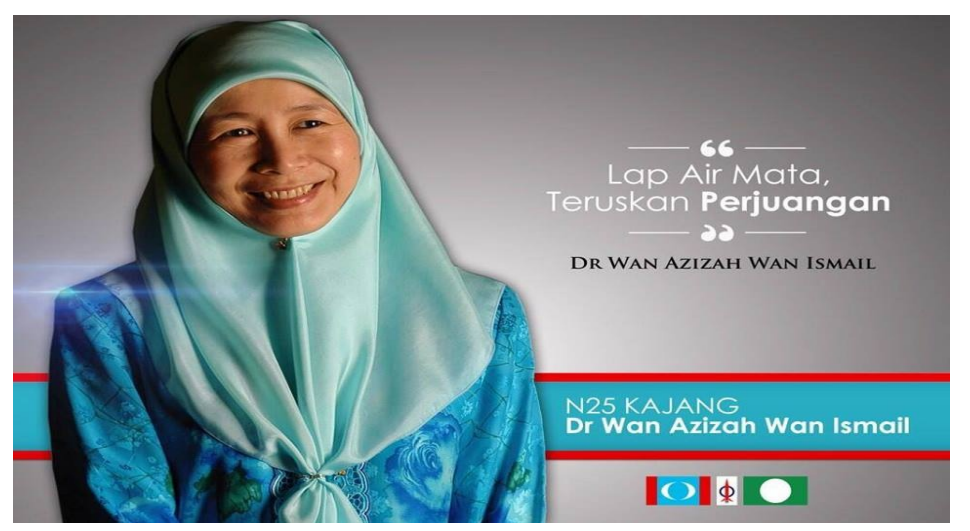

Figure 9. Advertisement by PKR, Dr. Wan azizah for voters’ sympathy (repetitive).

victory because people did actually support her husband and his ideals. The way she approached people with the slogan "Lap air mata, teruskan perjuangn" was to emphasize the sadness of being without her husband during the campaign. However:

Although there are some political analysts who opine that PKR puts Dr Wan Azizah Wan Ismail as the candidate to obtain sympathy votes, this columnist's PKR friend revealed that sympathy votes will not be forthcoming for her as the voters will vote based on who can be the better problem-solver (Tay, 2014).

This analysis from a political commentator recognized the strategy by Dr. Wan Azizah to get the sympathy vote. This is how PR influences its voters through psychology and appeals to emotion. A comparison is made between Chew Mei Fun who is single, and Dr. Wan Azizah who is missing hers and has been perceived as being treated unfairly. Basically all the elements of humaneness are employed to attract voters and get their attention.

\subsection{Findings of In-Depth Interviews}

\section{1) Confirming the effectiveness of political advertisements on Facebook}

The in-depth interviews confirmed that Facebook advertisements regarding the Kajang by-election had a great impact on voters. For instance R1 said,

Yes, in certain ways they did. Kajang's election is too much of a rumours and facebook did its job by spreading it and making an issue viral. That has helped in making the society always aware of the upcoming election although it was only a small one.

It is evident that Facebook is succesfully being used as the medium for political candidates to convey their political messages and benefits. As mention earlier, Facebook advertisements have the potential to promote the benefits of voting for certain political candidates. R1's response is supported by Messing and Westwood (2012) who states that social networks represent a fundamental break from traditional news modes and are templates for new forms of news discussion. Websites and mobile applications display content from many sources and users no longer have to select one news source when they have a wide-ranging discussion template.

\section{2) Facebook advertisements' strong influence during the campaining period}

From the textual analysis discussed earlier, some advertisements portray candidates' real concerns on political events. R2 stated that:

In my opinion, I will choose to look for more information of the campaign.

R2 is convinced that political campaigns through online medium do influence voters. Moten (2009) argues that online political advertising in Malaysia has increased in recent years because it is the key communication tool for a party. The purpose of political campaigning through social networks is to win an election. Doing this means using online media to share photos, opinions, etc. that are important to voters. The European Parliamentary Research Service by Davies (2014) contends that social media can be used in election campaigns in various ways, to organize a candidate's supporters and to persuade the as yet unconvinced. Social media encourages candidates to change their traditional reliance on mediators such as traditionally trained journalists. 
R3 stated that,

Facebook is one of the effective medium used to attract the society. So, by posting a status, activities that they have done for the society or using nice words when communicate with the Facebook user, it will surely give a good impact to those candidates.

The answer from R3 confirms previous research findings on the uses of social networks in our daily lives. People are using social networks to gain access to political candidates. In the Kajang by-election, not so much exposure is needed because Kajang is just a small "adun" but the key point is the effectiveness of Facebook advertisements. R3 said by posting their status and activities the political candidates revealed their concerns for society, not just in Kajang but for Malaysia as well. In contrast, R4 related the impact of the Kajang by-election to the case of Anwar Ibrahim and the recent MH370 tragedy. These incidents made the Kajang by-election more widely relevant and received much positive or negative comment. R4 explained this:

Facebook have a high impact on the elections in Kajang and at the same time Anwar Ibrahim was sentenced by the court and it started to spread in social media, then apply a bit of anger by supporters and it cause crowd gathered at kajang stadium to express dissatisfaction but it cannot be seen the ending because of mh370 tragedy happen on the same night.

A lot of speculation about the MH370 tragedy occurred and an effort was made to connect it with Anwar Ibrahim. However, this backfired when Dr. Wan Azizah, Anwar Ibrahim's wife, won the election. The effect of the campaign in social networking also can be seen through the comments that were posted on Facebook where certain people accused Anwar Ibrahim for the MH370 tragedy. This campaign tactic did not stop people voting for PR and it went on to win the election.

\section{3) Mixed feelings of voters towards online political campaigning}

Advertisements provided both negative and positive perceptions from voters. R5 stated that:

Yes, it gives a negative perception but in other ways it can be positive for people who have taken it as a political culture. Political candidates have their own way to promote their benefits and to attract voters to choose them.

Online political campaigns do attract voters. However, it is the content of advertisements that persuades people to vote or not to vote for a political candidate. The content of political advertisement has its own rules and aims not to be negative. Williamson, Miller and Fallon (2010) argue that political leaders accept the need to control the communication setting, and they will sense what the public desires and wants from online campaigns. Political parties also recognized that online campaigns depend on what happens during offline campaigns. The content of political advertising must suit the environment and target the right voter audiences. Politicians must monitor the content to control or negate any negative perceptions about them during a campaign.

4) Reputation of the Malaysian Political system

Online political advertisements must connect with voters directly. Social media networks are global in character and in this context; social media advertisements during an election campaign can be accessed by both Malaysians and non-Malaysians. For instance R4 said:

It affects the people who are hiding something, but for those who revealed will gain support. In the old days just rely on the traditional media means that elections are not as defection as now because voters need to know everything before voting.

It is evident that online political advertisements affect the political system in Malaysia in both positive and negative ways. In a positive way it will give a good impression to voters in that political candidates maintain relationships with citizens. In a negative way political activities can create racial or ethnic unrest, which is characteristic of Malaysia. For example, the Bersih Assembly increased many people's participation in street rallies for electoral reforms. R6 also supported this by stating:

Actually, online political campaign do affects Malaysian image in both ways, positive and negative way. Social media became a bridge to outsiders, allowed them to get a picture on political landscape in Malaysia. The negative way is our Malaysians are too obsessed about certain party politics and they didn't encouraged any discussion in public about others party politics. Even it happened, but end up the comments are full of insulted. 
According to research by the European Parliamentary Research Service (2014) the influence of social media during elections varies according to countries' political and electoral systems. Nevertheless even a small percentage of the population can (at least in some electoral systems) make a significant difference to the results of a party or an individual candidate. The answers from respondents prove that online political advertisements have impacted on the Malaysian political system in both positive and negative ways. Furthermore, according to R3:

Yes. Because online political campaign can be like a viral, as everyone and anybody in the world could view and access the campaign in Facebook. It does give the negative effect if it reflects the negative sides of the Malaysian political party.

R3 contends that online political advertisements have influenced Malaysia's image in that globally used social networks can promote a bad image when negative comments are made or reported during an election campaign. Advertisements and information can be manipulated by a third party or outsiders.

In contrast to this R1 remarked:

Universally, we are still under controlled compared to the developed country that practiced a full freedom of speech. We in Malaysia still bounded to law and for me, our country is still being viewed in positive ways.

Certain people abuse freedom of speech for political ends. From the statement above it can be concluded, however, that online political advertisements and campaigns create more positive perceptions rather than negative.

\section{5) The difference between online and mainstream media during political campaigns}

Online media are increasingly popular in election campaigns. As explained earlier, in the US Barack Obama use Facebook and Twitter to spread his political message and at the same time connect to citizens. This was replicated in Malaysia where people prefer to communicate online with their leaders. R4 commented on the differences between traditional and online political campaigning:

Cost, and target audience, if they target teenagers they will invest in social media campaign but they are candidate outside from urban area, usually they will use traditional media for campaign.

The main differences between traditional and online media political campaigning are cost and target audience. The traditional media campaign is more expensive but internet networks can be accessed everywhere. Social media users are mostly early adults and adult citizens that politicians want to reach in their campaigns. Rajaratnam (2009) highlighted that during the 2008 election the role played by the online media increased dramatically and especially during the recent 2013 election. R2 also the views concerning the importance of online media:

In my view, the social media political is worldwide but compare to traditional media campaign is just focus on certain location only.

The traditional media campaign as stated by R2 answer focused on certain regions only. The mainstream media focused on outside urban areas while online media covered both areas. This was typical of the Kajang by-election where the online media was more popular than traditional media developed technologies were part and parcel of urban life. The effectiveness of using online media is much greater than the traditional media because it covers a larger audience. R3 supported this contention:

For me, I would say that social media is the most effective way to influence the society is social media. Social media have the capability to attract the mass audience. Hence, the young adults like me might easily influence with the advertisement on social media.

The statement above has seen the effect of online political campaigning where it can retain a large target audience and particularly young adults who have voted for the first time. Social media is a place for communication for all ages, and in this context political candidates can persuade people through social online networks. In contrast R2 argues traditional media is still popular but people also are exposed to online media:

I will prefer social media as it's accessible and convenient to get the information about political campaign but using traditional media you can able to meet the political candidates face to face and we can report all the difficulties towards them. It depends on the availability of the individual and their preferences. 
The option whether to choose online media or mainstream media depends on individual preferences.

\section{Discussion}

\section{1) The role of political advertisements in social media networks}

The major finding is the power of using political advertisements on Facebook. Malaysiakini.com website on $8^{\text {th }}$ March 2014 reveals the promotion of leadership by emphasizing political candidates' activities with the public. It is evident that online political campaigning is effective because political advertisements are read by people online every day, so they connect with people. Political parties have to increase online campaigns because voters are increasingly online themselves and communicate in that way. Christopoulos (2013) states that influential politicians are noticeable through directed media (print, radio, television) but the structures of such media means they are not immediately accessible. Compliance-gaining theory can show how politicians attract voters and access their ideas of leaders or what they expect of them.

The Kajang by-election campaign witnessed online political advertising campaigns to attract voters in order to spread both parties' propaganda. Based on the screenshot using the BN candidate Chew Mei Fun, Facebook emphasized the role of BN's leadership. This was similar for the Opposition party candidate Dr Wan Azizah. The screenshot taken from her Facebook page reveals elements of leadership, as indicated in R1's statement. Other respondents are also influenced by the advertisements and what politicians did such as make donations to the poor and appeal to their emotions. According to Westling (2007) the media should be fair and objective when conveying information to the public. It should also hold the government to account by examining and authenticating the information it provides. So Facebook in political advertising has the same function as the traditional media in producing the messages that political parties want.

\section{2) The impact of online political advertising during the campaign period}

The next major finding is that the results of the Kajang by-election reflect online political advertising that voters see. Malaysiakini.com proved this on $24^{\text {th }}$ March 2014 immediately after the election results were announced. Malaysiakini.com is evidence that people are more attracted to what is published on Facebook and the way it persuades voters. R3 supported Malaysiakini.com's statement that Kajang will be ruled by the PR party. The interviews indicated that Facebook encouraged people in Kajang to vote for their preferred political candidate and updated events and politicians' opinions in order to attract social support.

\section{3) The content of online political campaigns}

Based on the major findings, it can be concluded that online political advertisements omit negative content and seek not to humiliate political rivals. The screenshots of Chew Mei Fun and Dr. Wan Azizah’s Facebook pages are evidence of this. This was supported by respondents who stated that negative content came from a third party that sort to manipulate content. An online political campaign should be monitored because there are many people who could manipulate the objectives of the campaign. This finding answered whether online political advertisements impacts on voters. It can be seen from the results and feedback given on the day of the Kajang by-election. PR had a good political campaign when Dr. Wan Azizah won.

\section{4) Effects on the Malaysian Political System}

The major findings do not mean that the Malaysian political system is unaffected. The online social media represent a worldwide view and can impact on the Malaysian political system where voters believe what is online but not in newspapers. It is supported by the statement from R4 that the days of relying on traditional media to get information about elections are gradually ending as online media assert their influence. Christine and Girish (2012) argue that candidates control and manipulate their profiles, discussion topics, posting of comments, videos and photographs. Facebook users who are "friended" by a candidate can also post material and comments. In practice this means that negative comments can be traced and isolated, which is a problem for the Malaysian political system.

\section{5) The manipulation of online political advertisements}

During the Kajang by-election candidates promoted notions of sympathy and honesty, as evident in the screenshot for $10^{\text {th }}$ March 2014 during the election campaign. It can be seen that PR advertisement promoted sympathy of Dr. Wan Azizah when she has replaced her husband. The interview session noted opinions that tallied with this observation. R4 answered that during the election campaign period Dr. Wan Azizah gained much support when her husband was charged in ambiguous circumstances. A slogan demonstrated the sadness of Dr. Wan Azizah in order to get the sympathy vote. The screenshot from Chew Mei Fun's Facebook page espouses 
her honesty in handling the crisis about her maid. R1 remarked that such crises strengthen a political candidate's power to win many voters.

Political advertisements that are online are presented differently from those in traditional media. The manipulation of advertisements will be greater because certain things happened before the Kajang by-election. According to Christopoulos (2013) social media's efficiency depends on the power of a personal connection. For example Dr. Wan Azizah had powerful connections with the Kajang people and got their vote due to support for her husband. The manipulation of online political advertisement occurs like it does in traditional media so that politicians get more votes. This finding emphasizes the compliance-gaining approach where Dr. Wan Azizah and Chew Mei Fun got voters' attention by having widespread political campaigns.

\section{Conclusion}

Using Facebook in political campaigns to attract voters is a good strategy due to the speed of information that audiences receive and respond to, regardless of age, gender and ethnicity. The utilization of both traditional media and online media needs to be balanced in order to reach targeted audiences and reduce the problem of the "digital divide". Negative elements that may harm the country's image through online political advertisement are unavoidable. Facebook cannot be censored in Malaysia and this allows outside people to witness the political and social changes occurring in the country. Online political campaigns will not damage Malaysia's political system and are in fact symbolic of healthy competition between the government (BN) and Opposition (PR) parties. At the same time, the media needs to be fair when covering news and political campaigns. The mainstream media is still important because previous elections have used them to target the non-developed areas like Sabah and Sarawak. In Kajang's by-election, it can be concluded that the usage of Facebook in conveying political messages was well received. However, political parties should be careful when using online social media because it can be manipulated by a third party or unknown person.

\section{References}

Andrew, W. (1992). Promotional Culture. Thousand Oaks, CA: Sage Publications Ltd.

ASLI (2008). An Analysis on 2008 General Elections. Report. Kuala Lumpur: Asian Strategy and Leadership Institute.

Braun, V., \& Clarke, V. (2006). Using Thematic Analysis in Psychology. Qualitative Research in Psychology, 3, 77-101.

Case, W. (1993). Semi-Democracy in Malaysia: Withstanding the Pressures for Regime Change. Pacific Affairs, 66, $183-205$.

Center for Public Integrity (2005). Democrats Likely to Choose Howard Dean as Leader. 8 February, Washington DC.

Channel News Asia (2014). Kajang By-Election Set for March 23. Channel News Asia, 5 February.

Charles, A., \& Gary, H. (2010). Effects of Political Advertising. The Public Opinion Quarterly, 40, 216-228.

Chinnasamy, S. (2013). A Study of the Impact of the Internet, Malaysiakini.com and Democratizing Forces on the Malaysian General Election. Adelaide: The University of Adelaide.

Christina, H.B., \& Lynda, L.K. (2006). Political Advertising in International Comparison. Thousand Oaks, CA: Sage Publications, 2-12.

Christine, B. W., \& Girish, J. G. (2007). Social Networks in Political Campaigns: Facebook and the 2006 Midterm Elections. Thousand Oaks, CA: Sage Publications, 1-23.

Christine, B. W., \& Girish, J. G. (2008). What Is Social Network Worth? Facebook and Vote Share in the 2008 Presidential Primaries (pp. 1-25). Thousand Oaks, CA: Sage Publications.

Christine, B. W., \& Girish, J. G. (2012). Social Network in Political Campaigns: Facebook and the Congressional Elections of 2006 and 2008 (pp. 51-71). Thousand Oaks, CA: Sage Publications.

Crouch, H. (1993). Malaysia: Neither Authoritarian nor Democratic. In K. Hewison, R. Robison, \& G. Rodan (Eds.), Southeast Asia in the 1990s: Authoritarianism, Democracy and Capitalism (pp. 135-158). St. Leonards: Allen \& Unwin.

Davies, R. (2014). Social Media in Election Campaigning. European Parliamentary Research Service 2014, 1-8.

Ernest, C. R., Jee, T. W., \& Lau, W. M. (2013). Negative Political Advertising: It's Impact on Voters. Asian Journal of Business Research, 3.

Franz, M. M., \& Ridou, T. N. (2007). Does Political Advertising Persuade? https://www.google.com.my/does+political+advertising+persuade

Freedman, P., Franz, M., \& Goldstein, K. (2004). Campaign Advertising and Democratic Citizenship. American Journal of Political Science, 48, 723-741. http://dx.doi.org/10.1111/j.0092-5853.2004.00098.x 
Frey, L., Botan, C., \& Kreps, G. (1999). Investigating Communication: An Introduction to Research Methods. Cambridge: Pearson.

Guy, C. (2001). The Language of Advertising. New York: Taylor and Francis Group.

Hassan, S. (1997). Asian Values and Democracy: Islamic Oriented Non-Governmental Organisations in Malaysia. Paper Presented at the 3rd International Workshop on Discourses and Practices of Democracy in Southeast Asia, Copenhagen.

Hitwise, E. (2008). Top Presidential Candidate 2008 Websites. United States.

Intelligence Unit’s Democracy Index (2011). Democracy Index 2011: Democracy under Stress: A Report from the Economist Intelligence Unit. The Economist, 4 December.

Kates, S. (1998). A Qualitative Exploration into Voters’ Ethical Perceptions of Political Advertising: Discourse, Disinformation, and Moral Boundarie. Journal of Business Ethics, 17, 1871-1885. http://dx.doi.org/10.1023/A:1005796113389

Lester, S. (1999). An Introduction to Phenomenological Research. www.sld.demon.co.uk/resmethy.pdf

Matthew, W. F. (2008). Left behind: A Textual Analysis of Media Frames from National TV Journalists Covering Hurricane Katrina's Evacuation Centers (pp. 1-75). Master's Thesis, Columbia, MO: University of Missouri-Columbia.

Messing, S., \& Westwood, S. (2012). Selecting Exposure in the Age of Social Media: Endorsements Trump Partisan Source Affiliation When Selecting News Online. http://crx.sagepub.com

Moten, A. R. (2009). 2004 and 2008 General Elections in Malaysia: Towards a Multicultural, Bi-Party Political System? Asian Journal of Political Science, 17, 173-194. http://dx.doi.org/10.1080/02185370903077469

Muzaffar, C. (1989). Challenges and Choices in Malaysian Politics and Society. Penang: Aliran Kesedaran Negara.

Oorjitham, S. (2008). New Media Spurring the Wind of Change. New Straits Times, 8 March 2008, 20-21.

Pew Internet \& American Life Project (2008). The Internet and the 2008 Election. Washington DC: Pew Research Centre.

Rajaratnam, U. D. (2009). Role of Traditional and Online Media in the 12th General Election, Malaysia. South East Asia Research Centre, 1, 33-58.

Rosemarie, A. (1997). Thematic Content Analysis (TCA) Descriptive Presentation of Qualitative Data.

Sani, M. A. M. (2005). Media Freedom in Malaysia. Journal of Contemporary Asia, 35, 341-367. http://dx.doi.org/10.1080/00472330580000201

Sindane, S. (2010). The Rise of Political Advertising on Television in South Africa and Its Implications for Democracy. Master's Thesis, Johannesburg: University of the Witwatersrand.

Tamara, A. S. (2008). The Facebook Effect? On-Line Campaigning in the 2008 Canadian and US Elections. http://archive.irpp.org/po/archive/nov08/small.pdf

Tan, E., \& Ibrahim, N. (2008). Blogging and Democratization in Malaysia: A New Civil Society in the Making. Kuala Lumpur: Sage Publications.

Themalayianinsider.com (2014). Kajang Rep Quits for By-Election, Anwar or Rafizi Slated to Stand. The Malaysian Insider, 27 January.

Valentino, N. A., Hutchings, V. L., \& Williams, D. (2004). The Impact of Political Advertising on Knowledge, Internet Information Seeking, and Candidate Preference. Journal of Communication, 54, 337-354. http://dx.doi.org/10.1111/j.1460-2466.2004.tb02632.x

Vogel, K. (2007). Money Bomb: Ron Paul Raises \$ 6 Million in 24-Hour Period. USA Today (The Politico), 17 December.

Welsh, B. (2004). Real Change? Elections in the Reformasi Era. In E. T. Gomez (Ed.), The State of Malaysia: Ethnicity, Equity and Reform (pp. 131-156). New York: Routledge Curzon.

Westling, M. (2007). Expanding the Public Sphere: The Impact of Facebook on Political Communication (pp. 1-13).

Williams, P. A., \& Tedesco, J. C. (2006). The Internet Election: Perspectives on the Web in Campaign 2004. Lanham, MD: Rowman \& Littlefield.

Zakaria, H. A. (1989). Malaysia: Quasi Democracy in a Divided Society. In L. Diamond, J. J. Linz, \& S. M. Lipset (Eds.), Democracy in Developing Countries: Asia (Vol. 3, pp. 347-381). Boulder, CO: Lynne Rienner. 